\title{
RAPIDLY-LABELLED, ACIDIC PHOSPHOLIPIDS OF THE GOLDFISH BRAIN ${ }^{1}$
}

\author{
J. Hollander, ${ }^{2}$ J. M. Hallenbeck and B. W. Agranoff \\ Mental Health Research Institute and Departments of Biological Chemistry and Neurology, \\ University of Michigan, Ann Arbor, Michigan 48104
}

(Received 21 November 1969. Accepted 16 February 1970)

\begin{abstract}
Homogenates and particulate fractions of goldfish brain incorporated radioactivity from $\gamma-\left[{ }^{32} \mathrm{P}\right]$ ATP selectively into acidic phospholipids during brief periods of incubation. Phosphatidate and lysophosphatidate became strongly labelled and activity was also found in phosphatidyl inositol phosphate and in phosphatidyl inositol diphosphate. When tetraphenylborate (a $\mathrm{K}^{+}$-complexing agent) was added, a selective stimulation of incorporation of ${ }^{32} \mathrm{P}$ into phosphatidate occurred. The addition of perchlorate (also known to bind $\mathrm{K}^{+}$) did not produce a similar stimulation, nor did the addition of $\mathrm{K}^{+}$block the stimulation by tetraphenylborate. The stimulation of the labelling of phospholipids by tetraphenylborate appeared to be the result of multiple actions. Besides the evidence that it acted by stimulating the phosphoinositide phosphodiesterase of brain, data were obtained suggesting that it stimulated diglyceride kinase and blocked endogenous destruction of ATP as well. The stimulation by tetraphenylborate was blocked by addition of atropine but not of arecoline.
\end{abstract}

ThE PHOSPHOINOSITIDEs, although ubiquitous in animal tissues, frequently exist in trace amounts demonstrable only by tracer methods. The greater content of phosphoinositides in excitable tissues (FolCh-PI, 1949; DAwson and DitTMER, 1961; BROCKERHOFF and BALLOU, 1962) and the evidence from labelling experiments of rapid turnover (DAwson, 1954; HoKIN and HokIN, 1958; ANSELl and SPANNER, 1959; LeBaron, Kistler and Hauser, 1960; Hölzl and Wagner, 1964; Kfoury and KERR, 1964; SEIFFERT and AGRANOFF, 1965) have suggested an important physiological role for these compounds in excitable tissues. Alterations of the labelling of phosphatidyl inositol $(\mathrm{PhI})$ and phosphatidic acid $(\mathrm{PhA})$ have been described in a variety of neural and secretory tissues in response to the appropriate neurohumor or secretagogue (cf. reviews by: HAwTHORNE, 1960; HoKIN and HoKIN, 1960; CuTHBERT, 1967). In sympathetic ganglia increased labelling has been correlated with synaptic transmission (LARRABEe and LEICHT, 1965; LARRABEE, 1968). Recently DURELL, GARLAND and FRIEDEL (1969) have suggested that such alterations are the result of activation of phosphatidyl inositol phosphodiesterase releasing diglyceride and inositol phosphate, but the detailed mechanism of the effect of acetylcholine remains speculative. The present experiments were undertaken to clarify the nature of these alterations in phospholipid labelling. The goldfish was selected because of the current interest in this laboratory in goldfish behaviour and its metabolic consequences. Various aspects of the labelling patterns of phospholipids in the goldfish brain, the effects of acetylcholine in goldfish brain, and the stimulation by tetraphenylborate of phospholipid labelling comprise the present report.

${ }^{I}$ Supported by grant NB3101 of the United States Public Health Service. A preliminary communication of some of these results has been reported (HollaNDER, HALLENBECK and AGRANOFF, 1969).

${ }^{2}$ Special Fellow of the NINDS, 2F 11NB 1900. Present address: Department of Neurology, University of Rochester, Rochester General Hospital, Rochester, New York 14621.

Abbreviations used: PhA, phosphatidic acid; PhI, phosphatidyl inositol; PhIP, phosphatidyl inositol phosphate; $\mathrm{PhIP}_{2}$, phosphatidyl inositol diphosphate; TPB, sodium tetraphenylborate. 


\section{MATERIALS AND METHODS}

Preparation of tissue. Homogenates of 25 brains (wet wt. about $80 \mathrm{mg}$ each) from common goldfish (Carassius auratus; body wt. 8.5-11 g) were prepared with 3 vol. of $0.25 \mathrm{M}$-sucrose and were used directly or as a source of subcellular fractions. After removal of cellular debris by centrifugation at $1000 \mathrm{~g}$ for $10 \mathrm{~min}$, a crude mitochondrial fraction was obtained by centrifugation at $20,000 \mathrm{~g}$ for $10 \mathrm{~min}$. The post-mitochondrial supernatant fraction was either used as such or a microsomal pellet was sedimented by centrifugation of this fraction at $100,000 \mathrm{~g}$ for $60 \mathrm{~min}$. The resulting pellet was washed once and resuspended in $0.25 \mathrm{M}$-sucrose. In other studies, after removal of cellular debris, homogenates were frozen (in a dry ice-acetone bath) and thawed three times, and the material was sedimented at $100,000 \mathrm{~g}$ for $60 \mathrm{~min}$, washed once, resuspended in $0.25 \mathrm{M}$-sucrose, and was used directly or stored frozen (particulate fraction). For experiments with brain minces, pooled brains of goldfish in Krebs-Ringer bicarbonate buffer (UMBREIT, BURRIS and STAUFFER, 1957) were minced finely with a scissors; $100-105 \mathrm{mg}$ of tissue were blotted with Whatman 54 filter paper, weighed, and suspended in $1.86 \mathrm{ml}$ of the buffer. For the regional studies, brains of five fish were dissected freehand into forebrain, tectum, tegmentum, cerebellum and vagal lobes. Each regional sample was divided into an experimental and control portion by sectioning in the median sagittal plane.

Incubation and extraction. All incubations were carried out at $20^{\circ} \mathrm{C}$. Homogenates or subcellular particles from $60 \mathrm{mg}$ of brain were incubated, with shaking, in a final vol. of $1.2 \mathrm{ml}$ containing $33 \mathrm{~mm}$ glycylglycine buffer ( $\mathrm{pH} 7.4), 8.3 \mathrm{~mm}-\mathrm{NaF}, 8.3 \mathrm{mM}^{-\mathrm{MgCl}_{2}}$ and $5 \mu \mathrm{Ci}$ of either ${ }^{32} \mathrm{P}_{1}(0.08 \mu \mathrm{mol})$, $\gamma$-[ ${ }^{32}$ P]ATP or $\gamma$-[ ${ }^{88}$ P]ATP $(0.1-0.2 \mu \mathrm{mol})$. In experiments designed to label PhI, $0.1 \mathrm{~mm}-\mathrm{CTP}$ and $0.1 \mathrm{~mm}$-myo-inositol were also present.

Minces were incubated with $5.5 \mu$ mols of inositol, $1.3 \mu \mathrm{mols}$ of glycerol, $11 \mu \mathrm{mols}$ of glucose, $5 \mu \mathrm{Ci}$ of ${ }^{32} \mathrm{P}_{1}$ and $1.86 \mathrm{ml}$ of Krebs-Ringer bicarbonate buffer (pH 7.4) in a total volume of $2 \mathrm{ml}$. In this case the final specific activity of the added ${ }^{32} \mathrm{P}_{1}$ was $2 \cdot 26 \mu \mathrm{C} \mathrm{i} / \mu \mathrm{mol}$. Results are expressed either as the percentage of the initially added radioactivity that was incorporated into lipid or as nmols or pmols of lipid formed. In the latter instance, the amount of lipid formed was calculated from the specific activity of the $\gamma$-[ ${ }^{32}$ P]ATP added. When ${ }^{32} P_{1}$ was used, specific activity was calculated on the basis of the presence of $0.01 \mu \mathrm{mol}$ of $P_{1} / \mathrm{mg}$ brains and in experiments with Krebs-Ringer bicarbonate buffer, for the $P_{1}$ present. Incubations were terminated with chloroform-methanol-6N-HCl $(10: 20: 1$, by vol.) and were extracted and washed as described previously (HAJRA, SEgUIN and AGRANOFF, 1968). Lipids were separated by TLC on oxalate-silica gel H plates (GoNZALEZ-SASTRE and FoLCH-PI, 1968) developed with chloroform-methanol-4N-ammonia $(3: 3: 1$, by vol.). This effected good separations of phosphatidyl inositol diphosphate $\left(\mathrm{PhIP}_{\mathbf{2}}\right)$, phosphatidyl inositol phosphate (PhIP) and $\mathrm{PhI}$, but PhA and PhI were poorly resolved. Separation of the lipid on basic carbonate plates (SKIPSKI, Peterson and Barclay, 1962) developed with chloroform-methanol-glacial acetic acid-water (50:25:7:3, by vol.), separated $\mathrm{PhI}$ from $\mathbf{P h A}$, while poorly resolving $\mathbf{P h I P}$ from $\mathbf{P h I P}_{2}$. By using both the oxalate and carbonate plates, each class of labelled lipids could be resolved and quantitated. The identity of the labelled lipids was confirmed by paper chromatography on formaldehyde-treated filter paper (HAJRA et al., 1968) and by high-voltage electrophorisis (SEIFFERT and AGRANOFF, 1965) of their deacylated glycerophosphates (HüBscher, HAwTHORNE and KEMP, 1960). The labelled regions were located by radioscanning or by autoradiography. The located spots were then cut out or scraped off and counted in $10 \mathrm{ml}$ of toluene containing $5 \%(\mathrm{v} / \mathrm{v})$ ethanol, $0.5 \%(\mathrm{w} / \mathrm{v})$ PPO and $0.03 \%$ (w/v) dimethyl POPOP by liquid scintillation spectrometry. In all experiments reported, duplicate incubation tubes were analysed. Variability was generally less than 10 per cent, although considerable variation was found from preparation to preparation of goldfish brain as seen below.

ATP and $P_{1}$ in the aqueous layer following lipid extraction of incubation mixtures were measured after high-voltage electrophoresis (HAJRA et al., 1968). Protein was determined by the method of LOWRY, ROSEBROUGH, FARR and RANDALL (1951) and phosphate by the method of CHEN, TORIBARA and WARNER (1956).

Materials. To obtain diglyceride, crude lecithin was prepared from eggs (HANAHAN, TURNER and $J_{A Y K O}, 1951$ ) and incubated at $37^{\circ} \mathrm{C}$ with $C$. perfringens phospholipase C(EC 3.1.4.3) (Sigma Chemical Co., St. Louis, Mo.; Schwartz Biochemicals, Brooklyn, N.Y.) in the presence of $0.15 \mathrm{M}$-tris buffer $\left(\mathrm{pH} 7 \cdot 4\right.$ ) and $0.01 \mathrm{M}-\mathrm{CaCl}_{2}$. The product was purified by solvent fractionation (LoNG and MAGurRE, 1954). For purposes of incubation, diglyceride was pipetted in chloroform-methanol $(2: 1, \mathrm{v} / \mathrm{v})$, detergent was added, and the solvent was evaporated. The diglyceride-detergent mixture was emulsified in the incubation medium by sonication prior to the addition of enzyme. The compounds $\gamma$-[ ${ }^{32}$ P]ATP and $\gamma$-[ ${ }^{33}$ P]ATP were prepared enzymically (GLYNN and CHAPPELL, 1964). During the course of this work ${ }^{33} \mathrm{P}_{1}$ became commerically available and ${ }^{32} \mathrm{P}_{1},{ }^{33} \mathrm{P}_{1}$ and $\left[{ }^{3} \mathrm{H}\right]$ inositol were obtained from New England Nuclear Corp. (Boston, Mass.). Cytidinediphosphoryl[1,2-14C]choline was purchased from TracerLab (Boston, Mass.). Sodium tetraphenylborate, acetylcholine chloride, eserine (all from Sigma Chemical Co.), atropine (Pierce Chemicals, Rockford, Ill.), arecoline (Nutritional Biochemicals, Cleveland, Ohio) and carbamylcholine (Merck-Sharpe and Dohme, West Point, 
Pa.) were used as aqueous solutions. Arlacel 20, Arlex, Tween 20, Tween 40, Tween 80, Renex 698 and Myrj 52 (Atlas Chemical Co., Wilmington, Del.), Triton X-100 and Triton CF-54 (Rohm and Haas, Philadelphia, Pa.), Nonex (Union Carbide Corp., N.Y.) and Cutscum (Fisher Scientific, Pittsburg, Pa.) were added in benzene. Sodium dodecyl sulphate (Matheson, Coleman and Bell, Cincinnati, Ohio) and sodium deoxycholate (Mann Biochemicals, N.Y.) were added as aqueous solutions. Hexokinase (Boehringer and Söhne, Mannheim, Germany) was dialysed to remove $\left(\mathrm{NH}_{4}\right)_{2} \mathrm{SO}_{4}$.

\section{RESULTS}

\section{Effect of cholinergic agents on labelling of lipids}

Brain minces. The presence of $3 \times 10^{-4} \mathrm{M}$-eserine and acetylcholine $\left(10^{-3} \mathrm{M}-\right.$ $10^{-8} \mathrm{M}$ ) during a $2 \mathrm{~h}$ incubation invariably produced a $10-50$ per cent increase in total lipid radioactive phosphorus. Eserine alone was also stimulatory, and there was no apparent concentration optimum for ACh. Carbamylcholine, added in the absence of eserine, produced a comparable stimulation, and although a clear concentration gradient could not be obtained, all the concentrations used (from $10^{-3}$ to $10^{-8} \mathrm{M}$ ) were stimulatory. The concentration of $5 \times 10^{-5} \mathrm{M}$-carbamylcholine was selected for

TABLE 1.-EFFECT OF CARBAMYLCHOLINE ON INCORPORATION OF ${ }^{32} \mathrm{P}_{1}$ INTO PHOSPHOLIPIDS IN VARIOUS REGIONS OF GOLDFISH BRAIN

\begin{tabular}{|c|c|c|c|c|c|c|}
\hline & Region & Forebrain & Tectum & Tegmentum & Cerebellum & Vagal lobes \\
\hline \multirow[t]{4}{*}{1} & Wet wt./brain (mg) & $11 \cdot 4$ & $15 \cdot 3$ & $17 \cdot 3$ & $13 \cdot 4$ & $31 \cdot 4$ \\
\hline & $\begin{array}{l}\text { Control } \\
\left.\quad \text { (nmols of }{ }^{32} \mathrm{P}\right] \text { lipid formed) } \\
+ \text { Carbamylcholine } 5 \times 10^{-5} \mathrm{M}\end{array}$ & $4 \cdot 75$ & $9 \cdot 2$ & $11 \cdot 7$ & $6 \cdot 1$ & 13.5 \\
\hline & (nmols of $\left[{ }^{32} \mathrm{P}\right]$ lipid formed) & $5 \cdot 5$ & $10 \cdot 0$ & $13 \cdot 1$ & 9.6 & $15 \cdot 9$ \\
\hline & $\%$ Stimulation & $15 \cdot 7$ & 8.7 & 11.5 & 57.4 & $18 \cdot 1$ \\
\hline \multirow[t]{3}{*}{ II } & $\begin{array}{l}\text { Control } \\
\quad\left(\text { nmols of }\left[{ }^{32} \mathrm{P}\right] \text { lipid formed) }\right. \\
+ \text { Carbamylcholine } 5 \times 10^{-5} \mathrm{M}\end{array}$ & $4 \cdot 1$ & $7 \cdot 55$ & $9 \cdot 5$ & 5.35 & 11.6 \\
\hline & (nmols of $\left[{ }^{32} \mathrm{P}\right]$ lipid formed) & $5 \cdot 65$ & $8 \cdot 6$ & 11.9 & 8.65 & 15.9 \\
\hline & $\%$ Stimulation & $38 \cdot 5$ & $13 \cdot 3$ & $25 \cdot 3$ & $61 \cdot 4$ & $37 \cdot 1$ \\
\hline
\end{tabular}

Five fish brains were subdivided by dissection into the designated regions and each sample was hemisected. Minces of half of each pooled region were incubated for $2 \mathrm{~h}$ in $2 \mathrm{ml}$ of Krebs-Ringer bicarbonate buffer in the presence or absence of $5 \times 10^{-5} \mathrm{M}$-carbamylcholine and ${ }^{32} \mathrm{P}_{1}$ as described in Methods.

further studies. Labelled lipid/mg of brain (Table 1) was relatively high in tegmentum and vagal lobes. Stimulation of labelling by carbamylcholine was greatest in cerebellum (60 per cent) followed by forebrain and vagal lobes (16-39 per cent), with the smallest effect in the tectum. When carbamylcholine was added to minced cerebellar preparations, increased labelling occurred during the course of a $4 \mathrm{~h}$ incubation. Stimulation of incorporation by carbamylcholine was greatest in $\mathrm{PhI}$, with significant effects in $\mathrm{PhA}$ and $\mathrm{PhIP}$ as well, but relatively small increases in $\mathrm{PhIP}_{2}$ and phosphatidyl choline (Fig. 1). When eserine and acetylcholine $\left(10^{-4} \mathrm{M}\right)$ were added to cerebellar preparations, labelling of lipids by radiophosphorus was stimulated by 14 to 35 per cent and the effect was blocked by pre incubation with $10^{-6} \mathrm{M}$-atropine. Atropine alone did not inhibit labelling at concentrations as high as $10^{-4} \mathrm{M}$.

Homogenates and subcellular particles. Numerous attempts were made to demonstrate stimulation of lipid labelling by acetyl- and carbamylcholine in broken cell preparations from whole brains under various conditions. Only a small degree of 

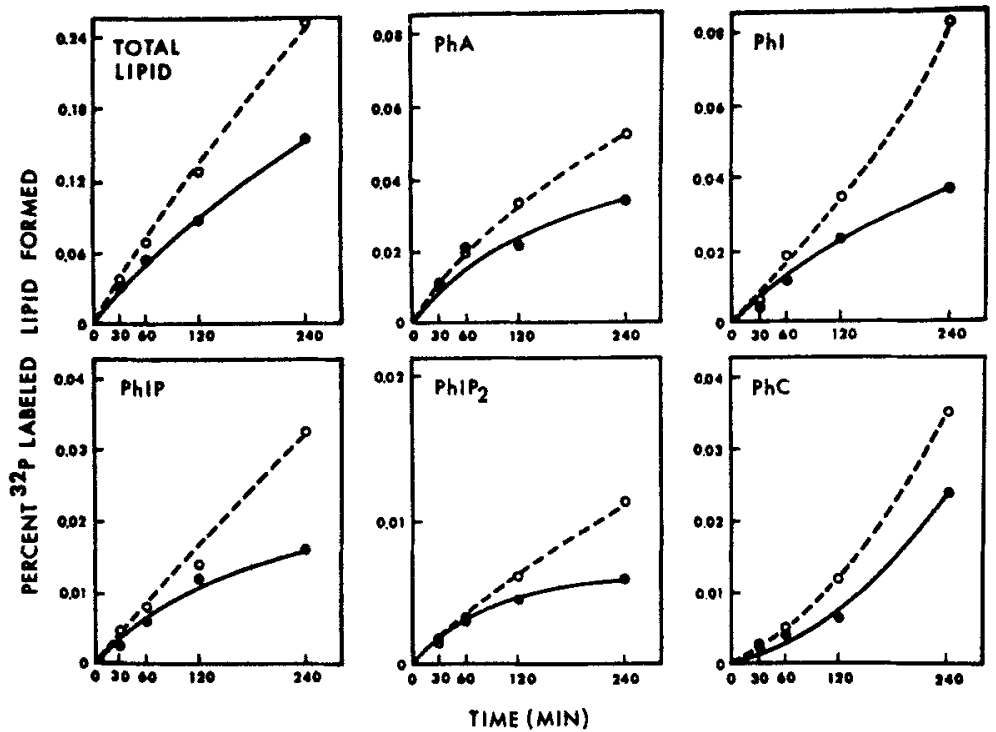

FIG. 1.-Labelling of individual lipids of goldfish brain in the presence or absence of $5 \times 10^{-5} \mathrm{M}$-carbamylcholine as a function of time of incubation. Minced cerebellar hemispheres $(33.5 \mathrm{mg})$ from five brains were incubated with $5 \mu \mathrm{Ci}$ of ${ }^{32} \mathrm{P}_{1}(1.03 \mu \mathrm{mols})$ for the times indicated. Following extraction, a portion of the total lipid was counted. Lipids were then separated by TLC and located by autoradiography. Solid lines, controls; dashed lines, +carbamylcholine. $\mathrm{PhC}=$ phosphatidyl choline.

stimulation was occasionally found and examination of individual lipids indicated that none was more strikingly stimulated in the presence or absence of fluoride or acetylcholine than the total extract.

\section{Composition of incubation medium}

At $\mathrm{pH} 7 \cdot 4$, glycylglycine was less inhibitory to labelling than Krebs-Ringer bicarbonate, tris or triethanolamine buffers and was used in further experiments even though lower, more poorly buffered concentrations of glycylglycine yielded considerably higher incorporation. The addition of $\mathrm{NaF}$ produced a three-fold increase of ${ }^{32} \mathrm{P}_{1}$ incorporation into lipids in homogenates, while the addition of $\mathrm{KF}$ was slightly more stimulatory. $\mathrm{CaCl}_{2}\left(2.1 \times 10^{-4} \mathrm{M}\right)$ was markedly inhibitory. Addition of potassium glutamate $\left(5 \times 10^{-4} \mathrm{M}\right)$ or glutathione $\left(5 \times 10^{-4} \mathrm{M}\right)$ was ineffective, and nicotinamide $\left(10^{-3} \mathrm{M}\right)$ was inhibitory. Additions of various nucleotides were without effect, except for AMP, which at $10^{-4} \mathrm{M}$ enhanced incorporation of ${ }^{32} \mathrm{P}_{\mathrm{i}}$ by about 10 per cent. Increasing the osmolarity of the medium with sucrose, $\mathrm{KCl}$ or $\mathrm{NaCl}$ proved to be inhibitory. These studies led to the choice of the standard incubation mixture already described in Methods. As previously observed in mitochondrial labelling systems (GAlliard, Michell and HAWTHORNe, 1965; ColodzIN and Kennedy, 1965; HaJRa et al., 1968; KaI, SAlWay and HAWthorne, 1968), $\gamma-\left[{ }^{32} \mathrm{P}\right] \mathrm{ATP}$ was a much better precursor of rapidly-labelled lipid than ${ }^{32} \mathrm{P}_{\mathrm{i}}$. In a standard incubation mixture $\gamma$-[ $\left.{ }^{32} \mathrm{P}\right] \mathrm{ATP}$ was somewhat superior to ${ }^{32} \mathrm{P}_{\mathrm{i}}$, but after freezing and thawing, only $\gamma-\left[{ }^{32} \mathrm{P}\right] \mathrm{ATP}$ could serve as a precursor, an observation in agreement with that reported by HAJRA et al. (1968). 


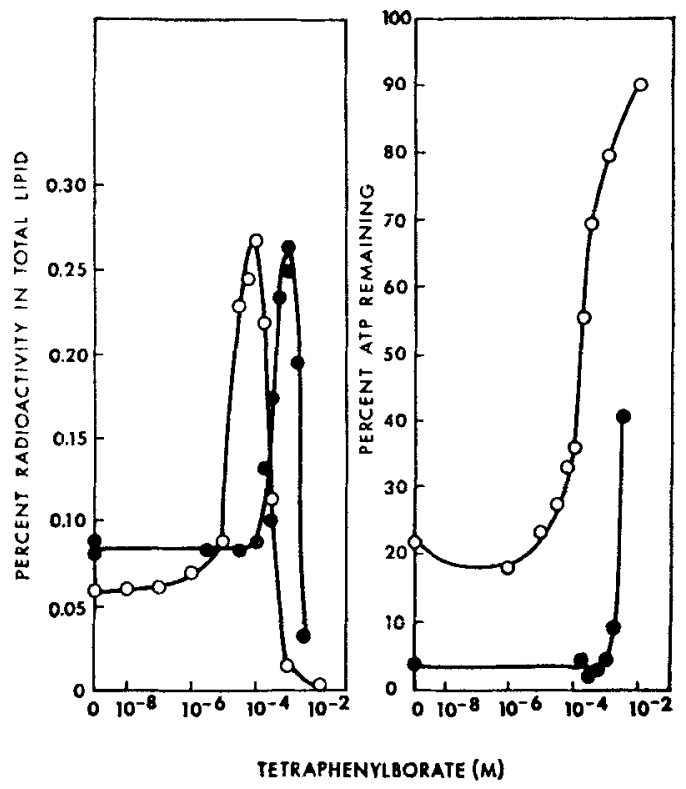

FIG. 2.-Effect of TPB on labelling of lipids and on hydrolysis of ATP in homogenates (C) $(6.0 \mathrm{mg}$ protein) or microsomal preparations $(O)(0.32 \mathrm{mg}$ protein) from goldfish brain. Samples were incubated for 15 min with varying final concentrations of TPB and $5 \mu \mathrm{Ci}$ of $\gamma$-[ $\left.{ }^{33 P}\right]$ ATP $(0.2 \mu \mathrm{mol})$. (a) Percentage of added radioactivity incorporated into lipid; (b) Percentage of added radioactivity remaining in ATP.

\section{Effects of sodium tetraphenylborate (TPB)}

The addition of TPB caused a dramatic increase in the labelling of lipids of homogenates of goldfish brain by $\gamma-\left[{ }^{32} \mathrm{P}\right]$ ATP, with a sharp optimum for TPB at $10^{-3} \mathrm{M}$ (Fig. 2). A sharp optimum $\left(10^{-4} \mathrm{M}\right)$ was also seen in labelling experiments with microsomal preparations. In each case the TPB to protein ratio was approximately the same, about $0.25 \mu \mathrm{mol}$ of TPB $/ \mathrm{mg}$ of protein. Clearly TPB also preserved ATP, particularly at concentrations which inhibited labelling of lipids. At $10^{-3} \mathrm{M}$, TPB stimulated labelling of lipids from $\gamma-\left[{ }^{32} P\right] A T P$ for all intervals of incubation of homogenates, mitochondria or post-mitochondrial supernatant fraction (Fig. 3). The cytosol $(100,000 \mathrm{~g}$ supernatant) fraction was not labelled. Although labelling of mitochondrial lipids was markedly stimulated, mitochondria were not studied further because of the anticipated difficulty in assessing the role of endogenous ATP production, particularly in the presence of TPB, a known inhibitor of oxidative phosphorylation (UTSUMI and PACKER, 1967).

Identification of labelled lipids. The increased labelling of lipids in homogenates from $\gamma-\left[{ }^{33} \mathrm{P}\right] \mathrm{ATP}$ during a $15 \mathrm{~min}$ incubation with $10^{-3} \mathrm{M}$ TPB was entirely due to a dramatic increase in labelling of $\mathrm{PhA}$ and an actual decrease in labelling of PhIP and $\mathrm{PhIP}_{2}$ (Fig. 4). In other experiments in which CTP and inositol were added to homogenates (see Table 5, below), PhI was labelled, and this labelling was also decreased by addition of TPB. In order to investigate further the nature of the TPB stimulation, microsomes were pre incubated with $10^{-4} \mathrm{M}-\mathrm{TPB}$ for $2 \mathrm{~min}$. In samples taken shortly after addition of $\gamma$-[ $\left.{ }^{33} \mathrm{P}\right] \mathrm{ATP}$ (Fig. 5), incorporation into lipids was 


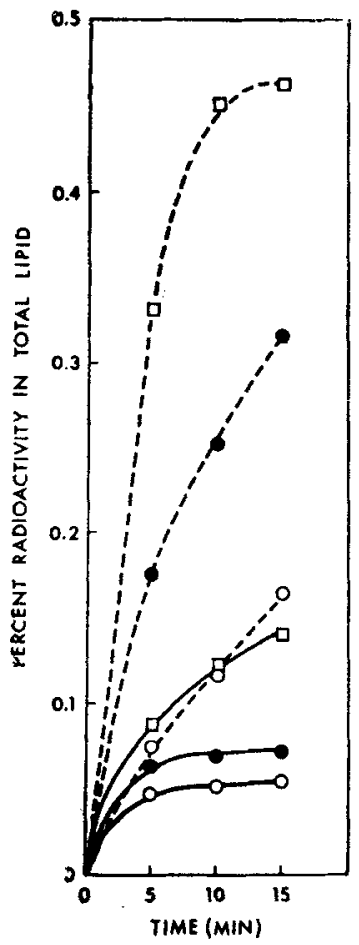

Fig. 3.-Labelling of lipids in various preparations from goldfish brain as a function of time of incubation. Homogenates $([))(6.0 \mathrm{mg}$ protein), mitochondria $(\bullet)(1.9 \mathrm{mg}$ protein) and the post-mitochondrial supernatant $(O)(2.1 \mathrm{mg}$ protein) were incubated with $5 \mu \mathrm{Ci}$ of $\gamma-{ }^{[s}$ P]ATP $(0.2 \mu \mathrm{mol})$ for the times indicated. Solid lines, controls;

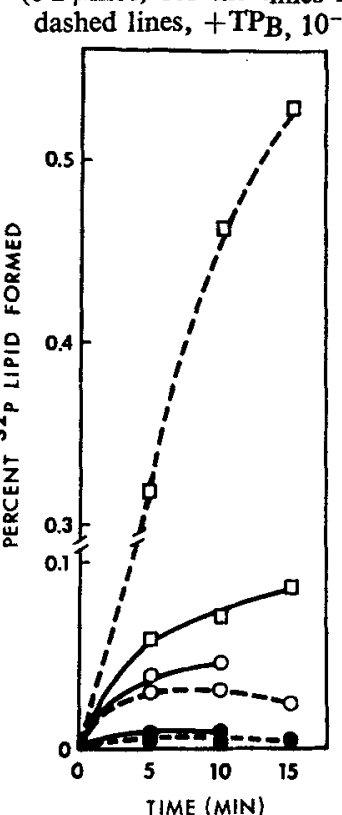

Fig. 4.-Labelling of individual lipids in the presence or absence of TPB as a function of time of incubation. Homogenates of goldfish brain were incubated with $5 \mu \mathrm{Ci}$ of $\gamma-\left[{ }^{\text {saP }}\right]$ ATP $(0.2 \mu \mathrm{mol})$ for the times indicated. PhA ( $\left.\square\right)$, PhIP (O), PhIP $(\bullet)$; solid lines, controls; dashed lines, +TPB, $10^{-3} \mathrm{M}$. 


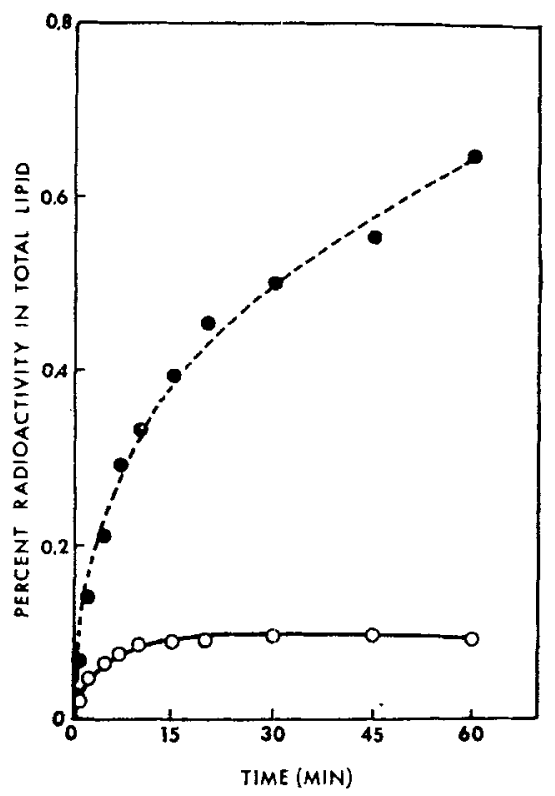

(a)

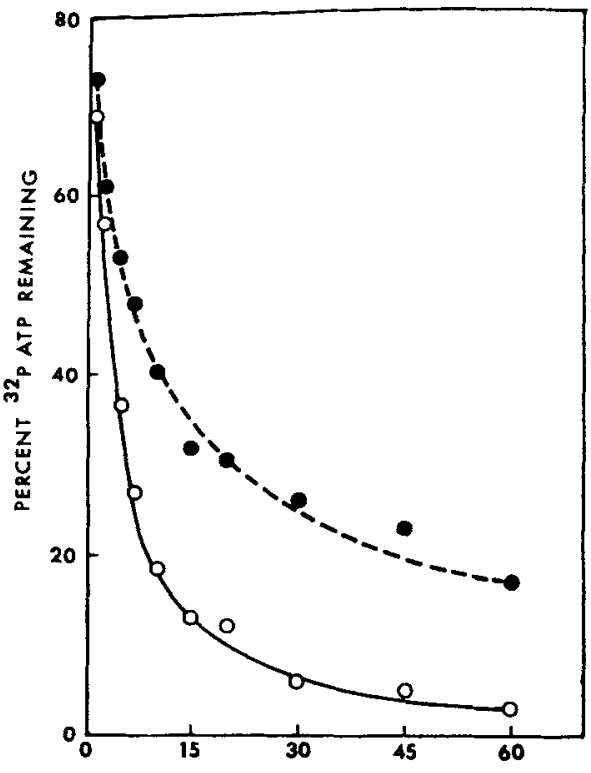

(b)

FIG. 5.-Labelling of lipids and hydrolysis of ATP in the presence or absence of TPB as a function of time of incubation. Microsomal preparations $(0.32 \mathrm{mg}$ protein) were incubated with $5 \mu \mathrm{Ci}$ of $\gamma-\left[{ }^{33} \mathrm{P}\right] \mathrm{ATP}(0.1 \mu \mathrm{mol})$ for the times indicated. (a) Total lipids. (b) ATP and $P_{i}$ were separated by electrophoresis at $4000 \mathrm{~V}$ on Whatman No. 1 paper, located by autoradiography and counted. Solid lines, control; dashed lines, + TPB.

stimulated, although little difference was yet evident in the amount of ATP remaining (Fig. 5). Labelling in the incubated controls appeared to have equilibrated by $10 \mathrm{~min}$. If the TPB was added simultaneously with ATP with no preincubation, there was a smaller degree of stimulation (Fig. 6a). If after a $15 \mathrm{~min}$ incubation, TPB was added together with the supplemental $\gamma$-[ $\left.{ }^{33} \mathrm{P}\right] \mathrm{ATP}$, a rapid rise in the labelling of PhA occurred (Fig. 6b) without evidence of a lag period, which might have been expected had endogenous diglyceride been consumed during the first 15 min. Findings on total lipids were similar (HoLLANDER et al., 1969), as were those in experiments with the particulate fraction incubated under similar conditions.

Effects of detergents, ions, and atropine. Further studies with the particulate preparation tested the possibility that TPB acted by release of endogenous diglyceride. Varying degrees of inhibition of the labelling of lipids were seen following addition to incubation mixtures of the nonionic detergents: preincubation mixture, $0.001-0.5 \mathrm{mg}$ of Tween 20 or $0.25-0.5 \mathrm{mg}$ of Tween 40, Tween 80 , Triton X-100, Triton CF-54, Nonex, Renex 698 or Myrj 52 . Arlex $(0.25-0.5 \mathrm{mg})$ had no effect on lipid labelling but decreased the effect of TPB, while Arlacel $20(0.05-0.5 \mathrm{mg})$ and Cutscum (0.05$0.5 \mathrm{mg}$ ) had no effect on either labelling or the TPB stimulation. An anionic detergent, sodium deoxycholate $\left(2.5 \times 10^{-3} \mathrm{M}\right)$ markedly stimulated labelling and its effect was abolished by TPB. This inhibitory interaction of TPB and deoxycholate occurred over a wide range of concentrations for each substance. Sodium dodecyl 


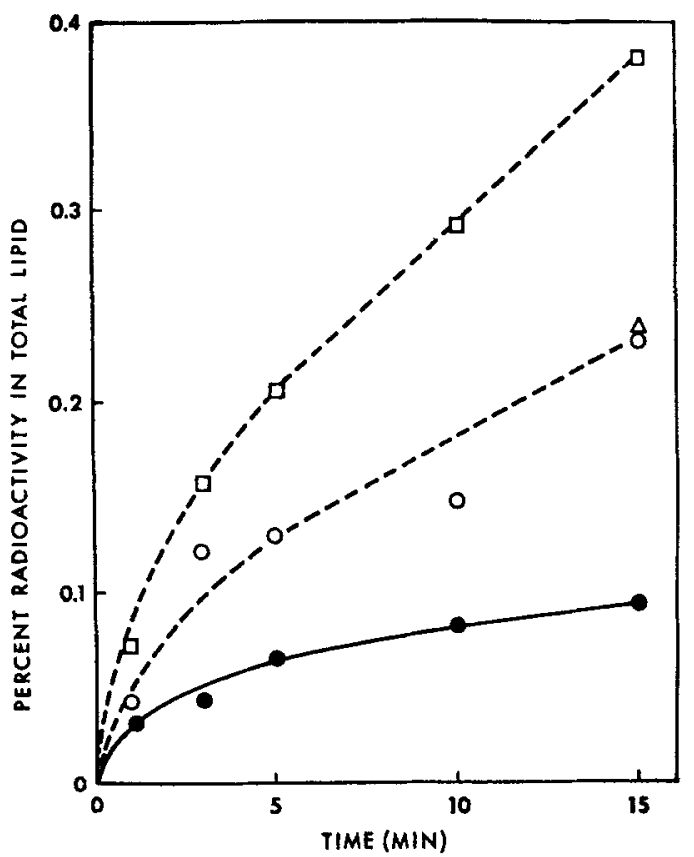

(a)

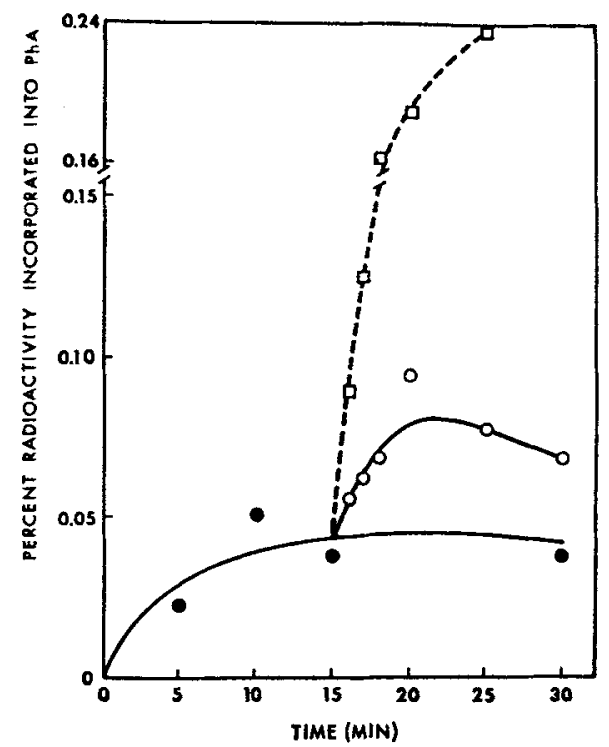

(b)

Fig. 6.-(a) Comparison of the effects of TPB present during pre incubation with those of TPB added simultaneously with ATP. Microsomal preparations from goldfish brain $\left(0.37 \mathrm{mg}\right.$ protein) were pre incubated for $10 \mathrm{~min}$ in the presence or absence of $10^{-6}$ M-TPB and then incubated with $5 \mu \mathrm{Ci}$ of $\gamma$-[35]ATP $(0 \cdot 2 \mathrm{~mol})$ for the times indicated. Solid line, control $(\bullet)$; dotted line, + TPB: (O) 10-4 M-TPB added with ATP; ( $\square$ ) $10^{-4} \mathrm{M}$-TPB added during pre incubation; $(\triangle) 10^{-4} \mathrm{M}$-TPB added with ATP without preincubation. (b) Effect of delayed addition of supplementary ATP with and without TPB. Microsomes ( $0.34 \mathrm{mg}$ protein) were incubated with $5 \mu \mathrm{Ci}$ of $\gamma-\left[{ }^{38} \mathrm{P}\right] \mathrm{ATP}(0.1 \mu \mathrm{mol})$ (0). An additional $5 \mu \mathrm{Ci}$ of the ATP (O) or $5 \mu \mathrm{Ci}$ of the ATP and $0.12 \mu \mathrm{mol}$ of TPB () were added at $15 \mathrm{~min}$. 
TABLE 2.-INFLUENCE OF ATROPINE AND ARECOLINE ON THE TETRAPHENYLBORATE ENHANCEMENT OF THE LABELLING OF PHOSPHOLIPIDS IN PARTICULATE PREPARATIONS FROM GOLDFISH BRAIN

\begin{tabular}{clc}
\hline Experiment & \multicolumn{1}{c}{ Preincubation treatment } & $\begin{array}{c}\% \text { of radioactivity } \\
\text { incorporated }\end{array}$ \\
\hline I & Atropine at -5 min - & 0.055 \\
& Atropine at -5 min, TPB at -2 min & 0.056 \\
& TPB at -5 min, atropine at -2 min & 0.059 \\
& TPB at -5 min & 0.230 \\
& & 0.242 \\
\hline II & Arecoline at -5 min & 0.101 \\
& Arecoline at -5 min, TPB at -2 min & 0.086 \\
& TPB at -5 min, arecoline at -2 min & 0.269 \\
& TPB at -5 min & 0.310 \\
\hline
\end{tabular}

Particulate preparations $(1.5 \mathrm{mg})$ were preincubated for $5 \mathrm{~min}$ and then incubated with $5 \mu \mathrm{Ci}$ of $\gamma$-[ ${ }^{32}$ P]ATP $(0 \cdot 1 \mu \mathrm{mol})$. Atropine $\left(10^{-4} \mathrm{M}\right)$, arecoline $\left(10^{-4} \mathrm{M}\right)$, or TPB $\left(5 \times 10^{-4} \mathrm{M}\right)$ were added at the times indicated. In other experiments, TPB at $-10 \mathrm{~min}$ and at $-2 \mathrm{~min}$ had effects on labelling similar to those of TPB at $-5 \mathrm{~min}$ above.

sulphate $\left(10^{-3} \mathrm{M}\right)$ produced a profound inhibition of labelling. Following preincubation of microsomal preparations with $10^{-4} \mathrm{M}-\mathrm{TPB}$, the addition of 3 equivalents of $\mathrm{KCl}$ did not reverse the TPB-mediated increase of lipid labelling during the $60 \mathrm{~min}$ following the addition of $\gamma$-[32P]ATP. The addition of an equimolar amount of choline chloride was also without effect. At $10^{-3} \mathrm{M}$, a known potassium complexing agent, sodium perchlorate, had no effect on labelling of lipids in homogenates, but higher concentrations inhibited labelling. Because of the reported cholinergic action of TPB (see Discussion below), the possibility that atropine might block the enhancement by TPB of lipid labelling was examined. The TPB effect was completely blocked by $10^{-4} \mathrm{M}$-atropine, but a similar concentration of arecoline had no effect (Table 2).

Addition of lipids extracted from TPB-stimulated preparations. If the TPB effect were mediated via the release of diglyceride from endogenous lipids, addition of lipids extracted from such incubations might stimulate labelling of lipids by ATP in the absence of TPB. Particulate preparations from goldfish brain in 10 times the usual amount were incubated with $5 \times 10^{-4} \mathrm{M}$-TPB in the absence of ATP. In the control samples, TPB was added at the end of incubation just prior to extraction. Lipids were extracted from the two incubated samples and were chromatographed on a silica gel TLC plate with light petroleum-ether $(70: 30 \mathrm{v} / \mathrm{v})$. The area corresponding to that of authentic diglyceride was scraped off and formed into a small column from which the lipid was eluted with chloroform-methanol $(2: 1 \mathrm{v} / \mathrm{v})$. When a portion $(20 \%)$ of the lipids purified from each incubation was then incubated with the particulate fraction in the presence or absence of TPB, labelling of lipids was markedly increased only when TPB was present during the final incubation (Table 3). The relatively marginal effect of the added purified lipid might reflect destruction during purification of the small amount of diglyceride released in the preparatory incubation or lesser accessibility for labelling of the added diglyceride than of that produced in membranes, e.g. at a site near diglyceride kinase. When diglyceride produced enzymically from egg lecithin was added (Table 3), labelling of lipids from ATP was enhanced in the samples incubated without TPB, but still not to the degree seen in the presence 
TABLE 3.- THE EFFECT OF ADDITION OF EXOGENEOUS DIGLYCERIDE TO THE PARTICULATE FRACTION OF GOLDFISH BRAIN INCUBATED IN THE PRESENCE OR ABSENCE OF TETRAPHENYLBORATE

\begin{tabular}{lcc}
\hline \multicolumn{1}{c}{ Added lipid } & $\begin{array}{c}\text { \% of radioactivity incorporated into lipid } \\
\text { - TPB }\end{array}$ & $\begin{array}{c}\text { +TPB } \\
\text { None }\end{array}$ \\
Incubated and extracted particulates & 0.019 & 0.164 \\
TPB-incubated and extracted particulates & 0.020 & 0.186 \\
Diglyceride $(\mu \mathrm{g})$ & 0.026 & 0.195 \\
1 & & \\
5 & 0.018 & 0.166 \\
10 & 0.018 & 0.253 \\
50 & 0.022 & 0.209 \\
100 & 0.024 & 0.298 \\
200 & 0.039 & 0.423 \\
400 & 0.026 & 0.481 \\
& 0.033 & 0.327 \\
\hline
\end{tabular}

See text for details and discussion. Lipids to be added were extracted in the usual way, with omission of $\mathrm{HCl}$. The purified lipid was emulsified with $0.5 \mathrm{mg}$ of Cutscum and incubated with particulate preparations (1.5 mg protein) for $15 \mathrm{~min}$ with $5 \mu \mathrm{Ci}$ of $\gamma$-[32P]ATP $(0.2 \mu \mathrm{mol})$.

TABLE 4.- EFFECTS OF PREINCUBATION OF THE PARTICULATE FRACTION FROM GOLDFISH BRAIN WITH PHOSPHOLIPASE C

\begin{tabular}{|c|c|c|c|}
\hline \multirow[b]{2}{*}{$\begin{array}{l}\text { Particulate preparation } \\
\text { No preincubation }\end{array}$} & \multirow[b]{2}{*}{ Addition } & \multicolumn{2}{|c|}{$\begin{array}{l}\% \text { of radioactivity incorporated } \\
\text { into lipid }\end{array}$} \\
\hline & & $\begin{array}{l}-\mathrm{TPB} \\
0.066\end{array}$ & $\begin{array}{l}+ \text { TPB } \\
0 \cdot 247\end{array}$ \\
\hline Preincubated & $\begin{array}{l}\text { Phospholipase C } \\
\text { Sodium dodecyl sulphate }\end{array}$ & $\begin{array}{l}0.052 \\
0.146 \\
0.027\end{array}$ & $\begin{array}{l}-\overline{0.287} \\
0.007\end{array}$ \\
\hline $\begin{array}{l}\text { Pre incubated with } \\
\text { phospholipase C }\end{array}$ & $\begin{array}{l}\text { Phospholipase C } \\
\text { Sodium dodecyl sulphate }\end{array}$ & $\begin{array}{l}0.269 \\
0.257 \\
0.415\end{array}$ & $\frac{0.602}{0.792}$ \\
\hline
\end{tabular}

A particulate preparation (10-fold; $8.6 \mathrm{mg}$ of protein) was preincubated $20 \mathrm{~min}$ in the presence or absence of phospholipase $C(1.0 \mathrm{mg})$ in a total vol. of $12 \mathrm{ml}$. The phospholiphase $C$ was then removed by centrifuging at $100,00 \mathrm{~g}$ for $60 \mathrm{~min}$ and the pellet was washed once and resuspended in $2.5 \mathrm{ml}$ of $0.25 \mathrm{M}$-sucrose. The washed particulate fraction $(0.25 \mathrm{ml})$ was then incubated for 15 min with $5 \mu \mathrm{Ci}$ of $\gamma$-[32P]ATP $(0.1 \mu \mathrm{mol})$ in the presence or absence of $5 \times 10^{-4} \mathrm{M}$-TPB, $10^{-8} \mathrm{M}$-sodium dodecyl sulphate or $1.0 \mathrm{mg}$ of phospholipase $C$ in the usual $1.2 \mathrm{ml}$ volume.

of TPB. The combined addition of diglyceride and TPB produced the highest degree of labelling of lipids.

Addition of phospholipase $C$. Since diglyceride obtained from egg lecithin stimulated the preparation, a further attempt was made to produce diglyceride in situ by adding phospholipase $\mathrm{C}$ to the preparation during a $20 \mathrm{~min}$ pre incubation (Table 4). The use of a particulate preparation permitted sedimentation of the particles and removal of the soluble phospholipase $\mathbf{C}$ after the pre incubation. After this pretreatment, the phospholipids were labelled from ATP to the same extent as that seen with TPB. Enhanced labelling also occurred when phospholipase $C$ was added during incubation of previously untreated particulate preparations. Sodium dodecyl sulphate, which inhibited both the labelling of lipids and the effect of TPB, paradoxically stimulated the labelling of lipids in the presence or absence of TPB if the preparation had first been treated with phospholipase $\mathbf{C}$. 
TABLE 5.-EFFECT OF TETRAPHENYLBORATE ON PRELABELLED LIPIDS IN PREPARATIONS FROM GOLDFISH BRAIN

\begin{tabular}{|c|c|c|c|c|c|c|}
\hline \multirow{2}{*}{ Preparation } & \multirow{2}{*}{$\begin{array}{l}\text { Incubation } \\
\text { time }\end{array}$} & \multirow[b]{2}{*}{ Conditions } & \multicolumn{4}{|c|}{ pmols of [ [22P]lipid formed } \\
\hline & & & $\operatorname{PhA}$ & PhI & PhIP & PhIP $_{\mathbf{s}}$ \\
\hline \multirow{6}{*}{ Particulates } & 10 & - & $60 \cdot 6$ & $28 \cdot 8$ & $63 \cdot 4$ & $10 \cdot 4$ \\
\hline & 15 & $\mathrm{H}+\mathrm{G}^{*}$ at $+10 \min$ & $61 \cdot 6$ & $28 \cdot 4$ & $65 \cdot 2$ & $11 \cdot 6$ \\
\hline & 30 & $\mathrm{H}+\mathrm{G}$ at $+10 \min \dagger$ & $73 \cdot 4$ & $39 \cdot 2$ & $58 \cdot 4$ & $13 \cdot 4$ \\
\hline & 30 & $\begin{array}{l}\mathrm{H}+\mathrm{G} \text { at }+10 \mathrm{~min} \\
+\mathrm{TPB}_{+}^{+} \text {at }+15 \mathrm{~min}\end{array}$ & $80 \cdot 4$ & $37 \cdot 6$ & 45.6 & $12 \cdot 2$ \\
\hline & 30 & $-\dagger$ & $79 \cdot 8$ & $43 \cdot 2$ & 58.4 & $12 \cdot 6$ \\
\hline & 30 & $+\mathrm{TPB}_{+}^{+}$at $-2 \mathrm{~min}$ & $1152 \cdot 0$ & $80 \cdot 4$ & 43.8 & 10.4 \\
\hline \multirow{6}{*}{ Homogenate } & 10 & - & $79 \cdot 5$ & 35.6 & $59 \cdot 3$ & 21.9 \\
\hline & 15 & $\mathrm{H}+\mathrm{G}$ at $+10 \mathrm{~min}$ & $77 \cdot 3$ & $28 \cdot 5$ & $43 \cdot 1$ & $16 \cdot 5$ \\
\hline & 30 & $\mathrm{H}+\mathrm{G}$ at $+10 \mathrm{~min}$ & 86.7 & $36 \cdot 1$ & 43.9 & $15 \cdot 4$ \\
\hline & 30 & $\begin{array}{l}\mathrm{H}+\mathrm{G} \text { at }+10 \mathrm{~min} \\
+\mathrm{TPB} \S \text { at }+15 \mathrm{~min}\end{array}$ & 73.5 & $22 \cdot 1$ & $14 \cdot 0$ & $4 \cdot 6$ \\
\hline & 30 & - & $124 \cdot 5$ & $45 \cdot 8$ & $71 \cdot 7$ & 20.8 \\
\hline & 30 & $+\mathrm{TPB} \S$ at $-2 \mathrm{~min}$ & 284.9 & $12 \cdot 4$ & $6 \cdot 2$ & $3 \cdot 7$ \\
\hline
\end{tabular}

Yields are based on the specific activity of the added ATP $(10 \mu \mathrm{Ci} ; 0.2 \mu \mathrm{mol}$, for particulates; $5 \mu \mathrm{Ci} ; 0.1 \mu \mathrm{mol}$, for homogenates). Particulate preparations contained $1.5 \mathrm{mg}$ of protein; homogenates, $6.0 \mathrm{mg}$ of protein. ATP was added to the particulate fraction in divided doses at 0 and $5 \mathrm{~min}$.

* Hexokinase, $60 \mu \mathrm{g}$, and glucose, $40 \mu \mathrm{mols}$.

$\dagger 0.1 \mathrm{ml}$ of $\mathrm{H}_{2} \mathrm{O}$ added instead of TPB.

$+0.6 \mu \mathrm{mol}$ of TPB in $0.1 \mathrm{ml}$.

$\S 1.2 \mu \mathrm{mol}$ of TPB in $0.1 \mathrm{ml}$.

Addition of TPB to labelled lipids. Particulate preparations or homogenates of goldfish brain were preincubated with $\gamma-\left[{ }^{32} \mathrm{P}\right] \mathrm{ATP}$ for $10 \mathrm{~min}$ and the residual ATP was then destroyed by addition to each tube of glucose and hexokinase (Table 5). Upon addition of TPB and continued incubation, labelled $\mathrm{PhA}$ remained unchanged but radioactive phIP and $\mathrm{PhIP}_{2}$ underwent accelerated degradation, especially in homogenates. When preparations were incubated as in Table 5 but with $0.23 \mu \mathrm{Ci}$ of $\left[{ }^{3} \mathrm{H}\right]$ inositol $(0.12 \mu \mathrm{mol})$ plus ATP and varying amounts of TPB, incorporation of inositol was progressively inhibited with about 50 per cent reduction of incorporation at $2.5 \times 10^{-4} \mathrm{M}$ and 75 per cent inhibition at $10^{-3} \mathrm{M}$-TPB. In the presence of TPB, the incorporation into lipids of radioactivity from cytidinediphosphoryl $\left[1,2-{ }^{14} \mathrm{C}\right]$ choline $(0.1 \mu \mathrm{Ci} ; 0.011 \mu \mathrm{mol})$ was increased by 5 to 10 per cent. For the latter experiments, the particulate preparation was preincubated with TPB for $10 \mathrm{~min}$, and an equimolar amount of unlabelled choline was added just before the addition of the labelled CDP-choline to prevent possible precipitation of the radioactive precursor with TPB.

\section{DISCUSSION}

The molecular mechanisms by which the neurohumoral actions of acetylcholine are mediated are poorly understood. One of the best known biochemical correlates of the action of acetylcholine is the stimulation of labelling of phospholipids in tissue slices (HoKIN and HokIN, 1953), with PhA and PhI preferentially affected (CUTHBERT, 
1967). This phenomenon is general for slices from neural and secretory tissues in response to the appropriate neurohumor or hormone (HAWTHORNE, 1960; HoKIN and HoKIN, 1960; CUTHBERT, 1967) and is generally believed to result from the enzymic release of diglyceride (DuRELl et al., 1969). The enhanced labelling of $\mathrm{PhI}$ in cat sympathetic ganglia (but not in nerve trunks) during perfusion with acetylcholine and during physiological or electrical preganglionic stimulation, contrasted with the absence of such enhancement in antidromically stimulated or curarized ganglia, provides further evidence for a relationship between the stimulation of lipid labelling and the physiological action of acetylcholine (LARRABEE and LEICHT, 1965; LARRABEE, 1968).

Whatever the physiological role of acetylcholine may be in the central nervous system, its effect on labelling of brain lipids is pronounced, and brain is the only tissue in which this stimulation has been seen in subcellular preparations (HoKIN and HoKIN, 1958; DURELl and SODD, 1964). In our experiments, carbamylcholine stimulated labelling of lipids in minces of goldfish brain and the highest enhancement was found in cerebellum, in contrast to the relative distribution among regions of the guinea pig brain (HoKIN, HoKIN and SHELP, 1960). This may be a species difference (SILVER, 1967). In other species, subcellular fractions were less dramatically stimulated by acetylcholine or by carbamylcholine (HoKIN and HoKIN, 1958; REDMAN and HoKIN, 1964; DuRELl and SODD, 1964). We found a marginal effect with these agents, but the use of an unusual cholinergic drug, TPB, resulted in striking effects in all subcellular fractions examined. From our pharmacological evidence, a possible cholinergic basis for its effect on lipid labelling is suggested.

Sodium TPB was initially introduced as an analytical reagent because it forms insoluble salts with potassium, ammonium and choline ions but does not precipitate with sodium, lithium or divalent cations (FLASCHKA and BARNARD, 1960). TPB has been used to precipitate catecholamines for chromatographic analysis (HAUPTMANN and WINTER, 1966). Dilute solutions of TPB dissociate cells (RAPPAPORT, 1966), cause mitochondria to swell (HARRIS and LEONE, 1966), uncouple oxidative phosphorylation (UTSUMI and PACKER, 1967), inhibit light-induced uptake of monovalent cations by chloroplasts (HORTON and PACKER, 1968), and inhibit $\mathrm{Mg}^{2+}$-activated ATPase in the thyroid gland (STANBuRY and Wicken, 1969). Moreover TPB depolarizes neuromuscular junctions and causes a twitch in phrenic nerve-diaphragm preparations (GUIDERI, SEIFTER and SEIFTER, 1968). We propose that TPB produces a specific enhancement of the activity of phosphoinositide phosphodiesterase. It also prevents ATP hydrolysis and probably stimulates diglyceride kinase. The mechanism of the TPB effect may be unrelated to its reaction with potassium. Other biological effects of TPB appear to be independent of potassium-binding (UTSUMI and PACKER, 1967; Stanbury and WICKEN, 1969). The TPB effect reported here cannot be reproduced by the $\mathrm{K}^{+}$-complexing agent, sodium perchlorate, and the addition of $\mathrm{K}^{+}$ has no effect when added to a preparation preincubated with TPB.

In brain, phosphoinositide phosphodiesterase (THOMPSON and Dawson, 1964) cleaves $\mathrm{PhIP}$ and $\mathrm{PhIP}_{2}$ to diglyceride, inositol diphosphate and inositol triphosphate, respectively. Initially this enzyme was reported not to act on $\mathrm{PhI}$ but recent studies (THOMPson, 1967) suggest that it may do so by releasing inositol monophosphate and diglyceride. Release of inositol monophosphate from $\mathrm{PhI}$ has been reported in guinea pig brain preparation (FrIedel, Brown and DURELL, 1967). Specific brain enzymes act on phosphoinositides and phosphatidate to release diglyceride, whereas 
degradation of other phospholipids is mediated primarily via deacylation (ANSELL and HAWTHORNE, 1964). In animal tissues, enzymic activity that liberates diglyceride from other phospholipids (phospholipase C, lecithinase; BARKHOLZ, ROITMAN and GATT, 1966 ) is probably relatively minor. The release of diglyceride from the inositides has another unique aspect. Like other phospholipids, phosphoinositides have a characteristic fatty acid distribution with saturation of the fatty acid in the $1^{\prime}$ position of glycerol and unsaturation at the $2^{\prime}$ position, but additional specificity in phosphoinositides exists since the $1^{\prime}$ position is occupied predominantly by stearate and the $2^{\prime}$ position contains over 60 per cent arachidonate (SVENNERHOLM, 1968). Thus phosphodiesterase may play a key role in physiological processes that mediate the availability of the essential fatty acid, arachidonate, in brain. The enzyme is activated by cationic 'amphipathic' substances, such as cetyltrimethylammonium bromide, and inhibited by anionic detergents, including sodium dodecyl sulphate (THOMPSON and DAwson, 1964). TPB is not a conventional detergent but it is anionic and might be expected to inhibit rather than to stimulate the phosphodiesterase. Therefore TPB does not appear to produce its effect via a detergent action. Predictably from the proposed mechanism of the TPB stimulation, preincubation of preparations from goldfish brain with sodium dodecyl sulphate profoundly inhibits lipid labelling in the presence or in the absence of TPB (Table 4). When diglyceride is furnished, sodium dodecyl sulphate is no longer inhibitory, and a significant increase in labelling is seen.

Labelling of $\mathrm{PhA}$ by $\gamma-\left[{ }^{32} \mathrm{P}\right] \mathrm{ATP}$ is presumably mediated via diglyceride kinase (HokIN and HoKIN, 1959). Possible mechanisms of action of TPB include: (1) a blocking of the endogeneous destruction of ATP, (2) a stimulation of diglyceride kinase, (3) an increase in available diglyceride from inositides (hydrolysis in the large endogeneous pool of PhA itself by $\mathrm{PhA}$ phosphohydrolase could also produce diglyceride and increase labelling) or (4) a combination of the above possibilities. TPB delayed hydrolysis of ATP in our preparations (Fig. 5b) but this alone could not explain the stimulation of lipid labelling. The effect of TPB was evident within $1 \mathrm{~min}$, before substantial differences in the concentration of ATP were evident. There was no lag period in the stimulation by TPB (Fig. 5a). Preservation of ATP by TPB was greatest at concentrations inhibitory for labelling of lipids (Fig. 2). The addition of supplemental ATP alone to microsomal fractions produced only minimal increases in labelling of PhA (Fig. 6b). Therefore TPB does not appear to affect labelling of lipids solely via its effect on levels of ATP. By contrast, sequential addition of labelled ATP and TPB after preincubation without TPB (Fig. 6b) did markedly increase the labelling of PhA, a finding suggesting either that endogenous diglyceride was limiting and TPB increased its availability, or that TPB preserved ATP and stimulated diglyceride kinase as well. It is possible that TPB reacted slowly with an enzyme catalysing a rate limiting step, for example, diglyceride kinase, a phosphodiesterase, an acylase leading to diglyceride synthesis or inhibition of PhA phosphohydrolase. The decreased label in the inositides in the presence of TPB in contrast to the stimulation of $\mathrm{PhA}$, suggests that the former could be a source of diglyceride.

If stimulation of diglyceride kinase alone accounted for the TPB effect, we would have anticipated rapid initial labelling of $\mathrm{PhA}$ and little change in its final level (unless ATP or diglyceride were being consumed by competing reactions). The maximum level of labelling observed in control incubations did not approach that seen with TPB (Figs. 3-5). Since degradation of most of the added ATP was indeed 
occurring by unrelated reactions and this was inhibited by TPB (Fig. 5b), stimulation of diglyceride kinase could not be ruled out. The stability of prelabelled $\mathrm{PhA}$ (Table 5) indicates that TPB does not stimulate PhA phosphohydrolase. Furthermore, the presence of magnesium and fluoride should completely inhibit this enzyme (CoLEMAN and HüBSCHER, 1962). The stimulation by TPB of the labelling of PhA is thus attributable to multiple actions including the release of diglyceride from the inositides through the action of phosphoinositide phosphodiesterase and a probable enhancement of diglyceride kinase activity. Conservation of ATP, particularly at longer incubation times, also plays a role.

The differences in labelling of lipids in homogenates and in particulate preparations treated with TPB after trapping of ATP are compatible with present knowledge of subcellular distribution of enzymes in the guinea pig brain. PhIP kinase, phosphoinositide phosphodiesterase, $\mathrm{PhIP}_{2}$ monoesterase, PhIP monosterase, and PhI phosphodiesterase are primarily in the cytosol, while diglyceride kinase, $\mathrm{PhI}$ kinase and CDP-diglyceride:PhA transferase are particulate (HARWOOD and HAWTHORNE, 1969). Our present experiments with preparations of goldfish brain are consistent, since some phosphoinositide phosphodiesterase activity persisted in the particulate after fractionation, although as expected, larger effects on labelling of phosphoinositides are seen in homogenates.

The proposed effect of TPB on phosphoinositide phosphodiesterase might be the consequence of TPB binding guanidinium groups (FLASCHKA and BARNARD, 1960) either on the phosphodiesterase itself or on other membrane proteins. In contrast to other cholinergic agents the dramatic effects of TPB on subcellular fractions may be attributable to secondary effects of TPB on ATP and on diglyceride kinase which would tend to amplify its effect on the phosphoinositide phosphodiesterase. It is less likely that these other effects are related to its cholinergic action. In the guinea pig, acetylcholine does not affect diglyceride kinase (HokIN and HoKIN, 1959) and in a number of studies it does not spare ATP. The striking block of the TPB effect by atropine might be interpreted as evidence for an interaction of TPB with a cholinergic receptor or alternatively as precipitation of the tertiary amine with TPB. No visible precipitate is seen upon mixing TPB and atropine at $10^{-4} \mathrm{M}$ and further, a control experiment was performed with arecoline, another tertiary amine which shares the methylpiperidine structure with atropine but which differs from atropine pharmacologically in being a parasympathomimetic agent while atropine is parasympatholytic. The cholinergic action of TPB previously reported (GuIDERI et al., 1968) and these effects of drugs on labelling of lipids indicate a possible cholinergic role for TPB.

Acknowledgement-We wish to acknowledge the capable technical assistance of Mr. EDWARD SEGUIN.

\section{REFERENCES}

Ansell G. B. and HAwthorne J. N. (1964) Phospholipids p. 152. Elsevier, Amsterdam.

ANSEll G. B. and Spanner S. (1959) J. Neurochem. 4, 325.

Barkholz Y., Rotrman A. and GatT S. (1966) J. biol. Chem. 241, 3731.

BROCKRRHOFF H. and BALLOU C. E. (1962) J. biol. Chem. 237, 1764.

Chen P. S. JR., Tortbara T. Y. and Warner H. (1956) Analyt. Chem. 28, 1756.

Colleman R. and Hünscher G. (1962) Biochim. biophys. Acta 56, 479.

Colodzin M. and Kennedy E. P. (1965) J. biol. Chem. 240, 3771.

Cuthbert A. W. (1967) Pharmac. Rev. 19, 59.

DAwson R. M. C. (1954) Biochem. J. 54, 237.

DAwson R. M. C. and DitTMER J. C. (1961) Biochem. J. 81, 540. 
Durell J., Garland J. T. and Friedel R. O. (1969) Science, N. Y. 165, 862.

Durell J, and Sodd M. A. (1964) J. biol. Chem. 239, 747.

Flaschio H. and Barnard A. J, (1960) Adv. Analyt. Chem. Instr. 1, 1.

FolCh-PI J. (1949) J. biol. Chem. 177, 505.

Friedel R. O., Brown J. D. and Durell J. (1967) Biochim. biophys. Acta 144, 684.

Galliard T., Mitchell R. H. and Hawthorne J. N. (1965) Biochim. biophys. Acta 106, 551.

GlynN I. M. and Chappell J. B. (1964) Biochem. J. 90, 147.

Gonzalez-Sastre F. and Folch-Pi J. (1968) J. Lipid. Res. 9, 532.

Guideri G., Seifter E. and Seifter J. (1968) Pharmacologist 10, 177.

Hajra A. K., Seguin E. B. and Agranoff B. W. (1968) J. biol. Chem. 243, 1609.

Hanahan D. J., Turner M. B. and Jayko M. E. (1951) J. biol. Chem. 192, 623.

HARRIS C. C. and LeONE C. A. (1966) J. cell. Biol. 28, 405.

HaRwood J. L. and HaWTHORNe J. N. (1969) J. Neurochem. 16, 1377.

HaUptManN S. and Winter J. (1966). J. Chromat. 21, 338.

Hawthorne J. N. (1960) J. Lipid Res. 1, 255.

Hokin L. E. and Hokin M. R. (1958) J. biol. Chem. 233, 822.

HOKIN L. E. and HokIN M. R. (1960) In International Review of Neurology (edited by PFEIFFER C. C. and SmYthites J. R.) Vol. 2, p. 99. Academic Press, New York.

Hokin M. R. and Hokin L. E. (1953) J. biol. Chem. 203, 967.

HokIN M. R. and HokIN L. E. (1959) J. biol. Chem. 234, 1381.

Hokin M. R., Hokin L. E. and Shelp W. D. (1960) J. gen. Physiol, 44, 217.

Hollander J., Hallenbeck J. M. and Agranoff B. W. (1969) Biochem. biophys. Res. Commun. 35, 346.

HöLzL J. and WAGNER H. (1964) Biochem. Z. 339, 324.

Horton L. A. and PaCker L. (1968) Archs Biochem. Biophys. 128, 820.

Hübscher G., Hawthorne J. N. and Kemp P. (1960) J. Lipid Res. 1, 433.

Kai M., Salway J. G. and Hawthorne J. N. (1968) Biochem.J. 106, 791.

KFoury A. G. and Kerr S. E. (1964) Biochim. biophys. Acta 84, 391.

LaRrabeE M. G. (1968) $J$ Neurochem. 15, 803.

Larrabee M. G. and Leicht W. S. (1965) J. Neurochem. 12, 1.

LeBaron F. N., Kistler J. P. and Hauser G. (1960) Biochim. biophys. Acta 44, 170.

LoNG C. and Maguire M. F. (1954) Biochem.J. 57, 223.

Lowry O. H., Roserrough J. J., Farr A. L. and Randall R. J. (1951) J. biol. Chem, 193, 265.

Rappaport C. (1966) Proc. Soc. exp. Biol. Med. 121, 1022.

ReDman C. M. and Hokin L. E. (1964) J. Neurochem. 11, 155.

Seiffert U. B. and Agranoff B. W. (1965) Biochim. biophys. Acta 98, 574.

SILVer A. (1967) In International Review of Neurobiology (edited by PFeIfFER C. C. and SMYthres J,

R.) Vol. 10, p. 58. Academic Press, London.

Skipski V. P., Peterson R. F. and Barclay M. (1962) J. Lipid Res. 3, 467.

Stanbury J. B. and WiCken J. V. (1969) Biochim, biophys. Acta 178, 403.

SVENNERHOLM L. (1968) J. Lipid Res. 9, 570.

Thompson W. (1967) Can.J. Biochem. 45, 853.

Thompson W. and Dawson R. M. C. (1964) Biochem. J. 91, 237.

Umbreit W. W., Burris R. H. and Stauffer J. F. (1957) Manometric Technique, p. 149. Burgess, Minneapolis. Minn.

Utsumi K. and PaCker L. (1967) Archs Biochem. Biophys. 122, 509. 